\title{
Autoradiographic Localization of Sigma Receptor Binding Sites in Guinea Pig and Rat Central Nervous System with $(+)^{3} \mathrm{H}-3-(3-H y d r o x y p h e n y l)-\mathrm{N}-(1-p r o p y l) p i p e r i d i n e$
}

\author{
Andrew L. Gundlach, ${ }^{1}$ Brian L. Largent, and Solomon H. Snyder \\ Departments of Neuroscience, Pharmacology and Experimental Therapeutics, Psychiatry and Behavioral Sciences, \\ The Johns Hopkins University School of Medicine, Baltimore, Maryland 21205
}

$(+)^{3} \mathbf{H}-3-P P P\left[(+)^{3} \mathbf{H}-3-(3-H y d r o x y p h e n y l)-N\right.$-(1-propyl)-piperidine] binds with high affinity to brain membranes with a pharmacological profile consistent with that of sigma receptors. The distribution of $(+)^{3} \mathrm{H}-3-\mathrm{PPP}$ binding sites in brain and spinal cord of both guinea pig and rat has been determined by in vitro autoradiography with binding densities quantitated by computer-assisted densitometry. $(+)^{3} \mathrm{H}-3$-PPP binding to slidemounted brain sections is saturable and displays high affinity and a pharmacological specificity very similar to sites labeled in homogenates. $(+)^{3} \mathrm{H}-3-P P P$ binding sites are heterogeneously distributed. Highest concentrations of binding sites occur in spinal cord, particularly the ventral horn and dorsal root ganglia; the pons-medulla, associated with the cranial nerve and pontine nuclei and throughout the brain stem reticular formation; the cerebellum, over the Purkinje cell layer; the midbrain, particularly the central gray and red nucleus; and hippocampus, over the pyramidal cell layer. Lowest levels are seen in the basal ganglia and parts of the thalamus, while all other areas, including hypothalamus and cerebral cortex, exhibit moderate grain densities. Quinolinic acid-induced lesions of the hippocampus indicate that $(+)^{3} \mathbf{H}$-3-PPP labels hippocampal pyramidal cells and granule cells in the dentate gyrus. Intrastriatal injection of ibotenic acid dramatically reduces $(+)^{3} \mathbf{H}-3-P P P$ binding in this area, while injection of 6-hydroxydopamine produces a relatively slight decrease. The distribution of $(+)^{3} \mathrm{H}-3-P P P$ binding sites does not correlate with the receptor distribution of any recognized neurotransmitter or neuropeptide, including dopamine. However, there is a notable similarity between the distribution of $(+)^{3} \mathrm{H}-3-P P P$ sites and high-affinity binding sites for psychotomimetic opioids, such as the benzomorphan (+)SKF 10,047 .

The existence of three types of opioid receptors-mu, kappa, and sigma-was postulated to explain the effects of different opioids in chronic spinal dog preparations (Martin et al., 1976). Sigma receptors, named for the prototypic agonist SKF 10,047 ( $N$-allylnormetazocine), were suggested to mediate the psychotomimetic-like effects of SKF 10,047 in the dog. Similarities

\footnotetext{
Received Oct. 14, 1985; accepted Nov. 26, 1985
}

This work was supported by USPHS Grants DA-00266 and NS-16375, and Rescarch Scicntist Award DA-00074 to S.H.S.; National Institutes of Health Training Grant GM-07626 to B.L.L.; and a grant from the McKnight Foundation. A.L.G. is the recipient of a National Health and Medical Research Council (Australia) C. J. Martin Fellowship. We wish to thank Dawn C. Dodson and Ida M. Anderson for secretarial assistance and Paul F. Worley and Donald C. Manning for help with lesion studies and for providing spinal cord sections, respectively.

Correspondence should be addressed to Solomon H. Snyder, Departments of Neuroscience, Pharmacology and Experimental Therapeutics, Psychiatry and Behavioral Sciences, The John Hopkins University School of Medicine, 725 North Wolfe Street, Baltimore, MD 21205.

Present address: Department of Pharmacology, University of Sydney, Sydney, N.S.W. 2006, Australia.

Copyright (c) 1986 Society for Neuroscience $0270-6474 / 86 / 061757-14 \$ 02.00 / 0$ have been noted between the behavioral effects in animals and the psychotomimetic effects in man caused by such drugs (Haertzen, 1970; Keats and Telford, 1964). Many pharmacological effects of drugs such as SKF 10,047 and cyclazocine are not blocked by opioid antagonists, e.g., naloxone or naltrexone (Iwamoto, 1981; Vaupel, 1983; Young and Khazan, 1984), suggesting that these drugs interact at sites very different from more classical opiate receptors. Furthermore, the ability of benzomorphans to produce "sigma" or psychotomimetic-like behavioral effects generally resides more in the $(+)$ than the $(-)$ isomer (Brady et al., 1982; Katz et al., 1985; Slifer and Balster, 1983), a stereoselectivity opposite to that found at mu, kappa, or delta opiate receptors.

Binding sites in brain membranes with a drug specificity consistent with putative sigma receptors were first identified with $( \pm)^{3} \mathrm{H}-\mathrm{SKF} 10,047$ in the presence of unlabeled etorphine $\mathrm{Su}$, $1981,1982)$. Sigma receptor binding sites have also been labeled with $(+)^{3}$ H-SKF 10,047 (Gundlach et al., 1985; Largent et al., in press; Martin et al., 1984; Tam, 1983, 1985; Tam and Cook, 1984), (+) and $(+)^{3}$ H-ethylketocyclazocine (Tam, 1983, 1985) and ${ }^{3} \mathrm{H}$-haloperidol (Largent et al., 1984; Tam and Cook, 1984). Binding of $(+)$ and $(-)^{3} \mathrm{H}-\mathrm{SKF} 10,047$ to mouse brain membranes reveals that the isomers differ in drug specificity and regional distribution (Martin et al., 1984). Similarities in biochemical and behavioral effects of sigma opioids and phencyclidine (PCP) have suggested actions through a common receptor designated, sigma opioid/PCP receptor (Shannon, 1983; Zukin and Zukin, 1981). However, the regional distribution and pharmacology of $(+)^{3} \mathrm{H}-\mathrm{SKF}$ 10,047-labeled sigma receptor binding sites differ from ${ }^{3} \mathrm{H}-\mathrm{PCP}-$ labeled sites (Gundlach et al.,

Table 1. Comparison of drug potencies in inhibiting $(+)^{3} \mathbf{H}-3-P P P$ binding to brain sections and homogenates

\begin{tabular}{lll} 
& \multicolumn{1}{c}{$\mathrm{IC}_{50}(\mathrm{M})$} & \\
\cline { 2 - 3 } Drug & Brain section & $\begin{array}{l}\text { Brain } \\
\text { homogenate }\end{array}$ \\
\hline Haloperidol & $5.0 \times 10^{-9}$ & $3.0 \times 10^{-9}$ \\
$(-)$ Butaclamol & $4.2 \times 10^{-7}$ & $1.6 \times 10^{-7}$ \\
$(+) B u t a c l a m o l$ & $2.0 \times 10^{-5}$ & $2.0 \times 10^{-6}$ \\
Pentazocine & $4.0 \times 10^{-8}$ & $2.5 \times 10^{-8}$ \\
$(+)$ Cyclazocine & $1.3 \times 10^{-7}$ & $1.2 \times 10^{-7}$ \\
$(-)$ Cyclazocine & $1.5 \times 10^{-6}$ & $4.5 \times 10^{-7}$
\end{tabular}

Slide-mounted sagittal sections $(12 \mu \mathrm{m})$ of guinea pig brain were incubated with 4-5 $\mathrm{nM}(+)^{3} \mathrm{H}-3$-PPP in the presence of seven (triplicate) or 10 (duplicate) concentrations of drug, as described in Materials and Methods. $\mathrm{IC}_{5_{0}}$ values were calculated from the data using the EBDA computer program (McPherson, 1983). Values are the average of two determinations.

a Values from Largent et al. (1984). 

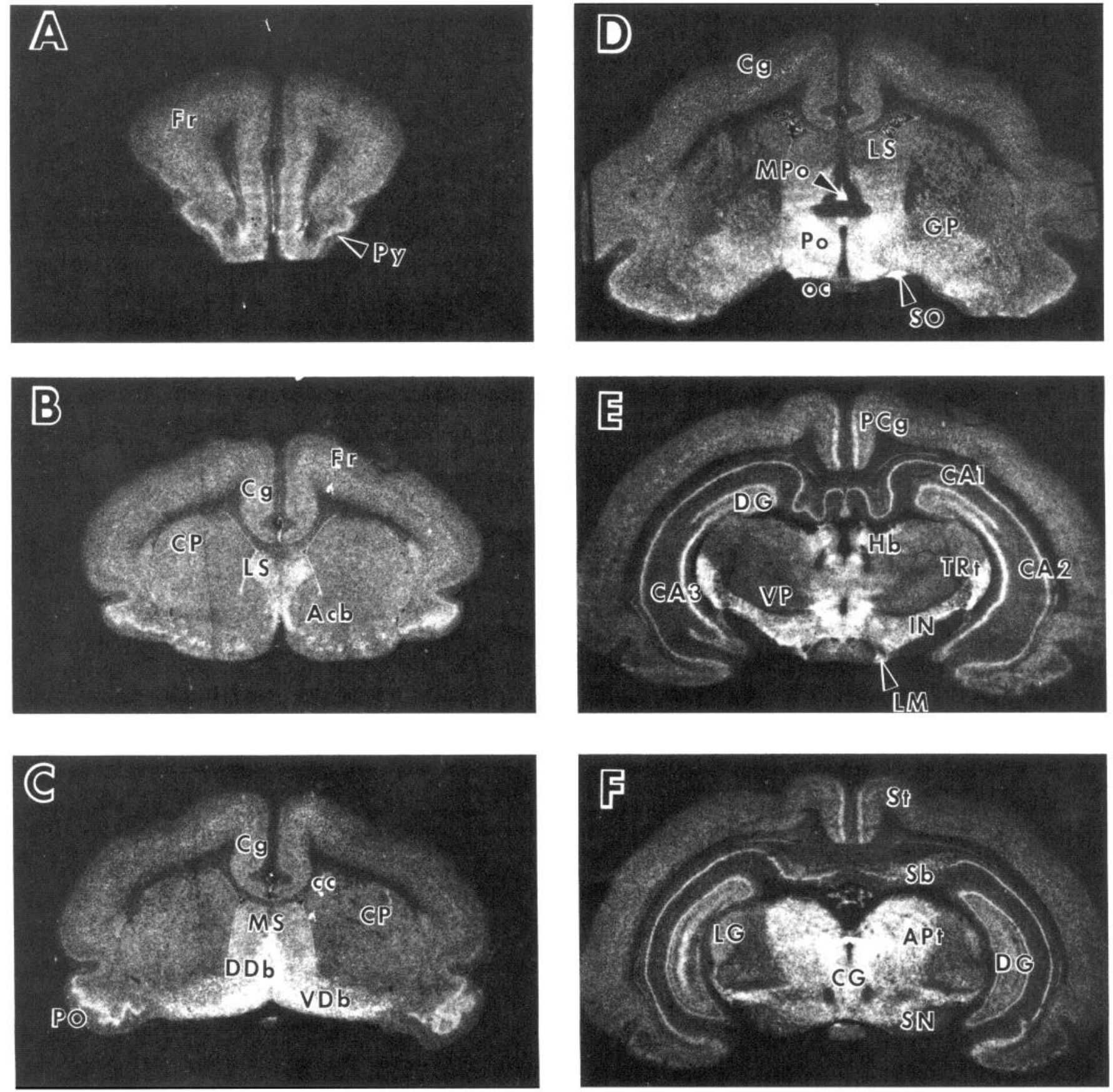

Figure 1. Autoradiograms detailing the anatomical distribution of $(+)^{3} \mathrm{H}-3$-PPP binding in guinea pig brain $(A-L)$. Representative brain sections are presented in a rostral-caudal progression. Increased whiteness in the photographs, printed directly from the Ultrofilm, corresponds to higher levels of $(+)^{3} \mathrm{H}$-3-PPP binding. As detailed in Materials and Methods, $8 \mu \mathrm{m}$ sections were incubated with $5 \mathrm{nM}(+)^{3} \mathrm{H}-3-\mathrm{PPP}$ for 45 min at room temperature, washed, dried, and apposed to Ultrofilm for 4 weeks at $4^{\circ} \mathrm{C}$. Nonspecific binding was measured in the presence of $1 \mu \mathrm{M}$ haloperidol and is less than labeling seen over white matter in these plates. Structures were identified by reference to the atlases of Luparello (1967) and Paxinos and Watson (1982). Acb, Accumbens nucleus (n.); $A m b$, ambiguus n.; $A P t$, anterior pretectal area; $C A 1-3$, fields CA-1, CA-2, CA-3 of Ammon's horn, hippocampus; $C b$, cerebellum; $c c$, corpus callosum; $C G$, central gray; $C g$, cingulate cortex; $C P$, caudate putamen; $D D b$, dorsal diagonal band of Broca; $D G$, dentate gyrus; $D T g$, dorsal tegmental n.; $E C u$, external cuneate n.; Ent, entorhinal cortex; Fac, facial n.; Fr, frontal cortex; $G n$,

1985; Largent et al., in press; Martin et al., 1984; Tam, 1983, 1985; Zukin and Zukin, 1979).

3-(3-Hydroxyphenyl)- $N$-(1-propyl)piperidine (3-PPP) and its enantiomers produce behavioral and biochemical effects in animals that are consistent with agonist actions at dopamine autoreceptors. These include in vivo effects similar to the dopamine agonist apomorphine, e.g., decreased nigral dopamine cell firing, reduction in the synthesis rate of dopamine in reserpine- or gammabutyrolactone-treated rats, and decreased locomotor ac- tivity (Arnt et al., 1983; Hjorth et al., 1981, 1983, 1985). However, in vitro, the lack of potency of 3-PPP in experimental systems thought to measure dopamine autoreceptor activity, such as inhibiting ${ }^{3} \mathrm{H}$-dopamine release from striatal slices (Markstein and Lahaye, 1983; Mulder et al., 1985; Sminia and Mulder, 1983) and decreasing tyrosine hydroxylase activity in synaptosomes (Haubrich and Pflueger, 1981), is inconsistent with the in vivo findings and calls into question the mechanism underlying 3-PPP's in vivo effects. 

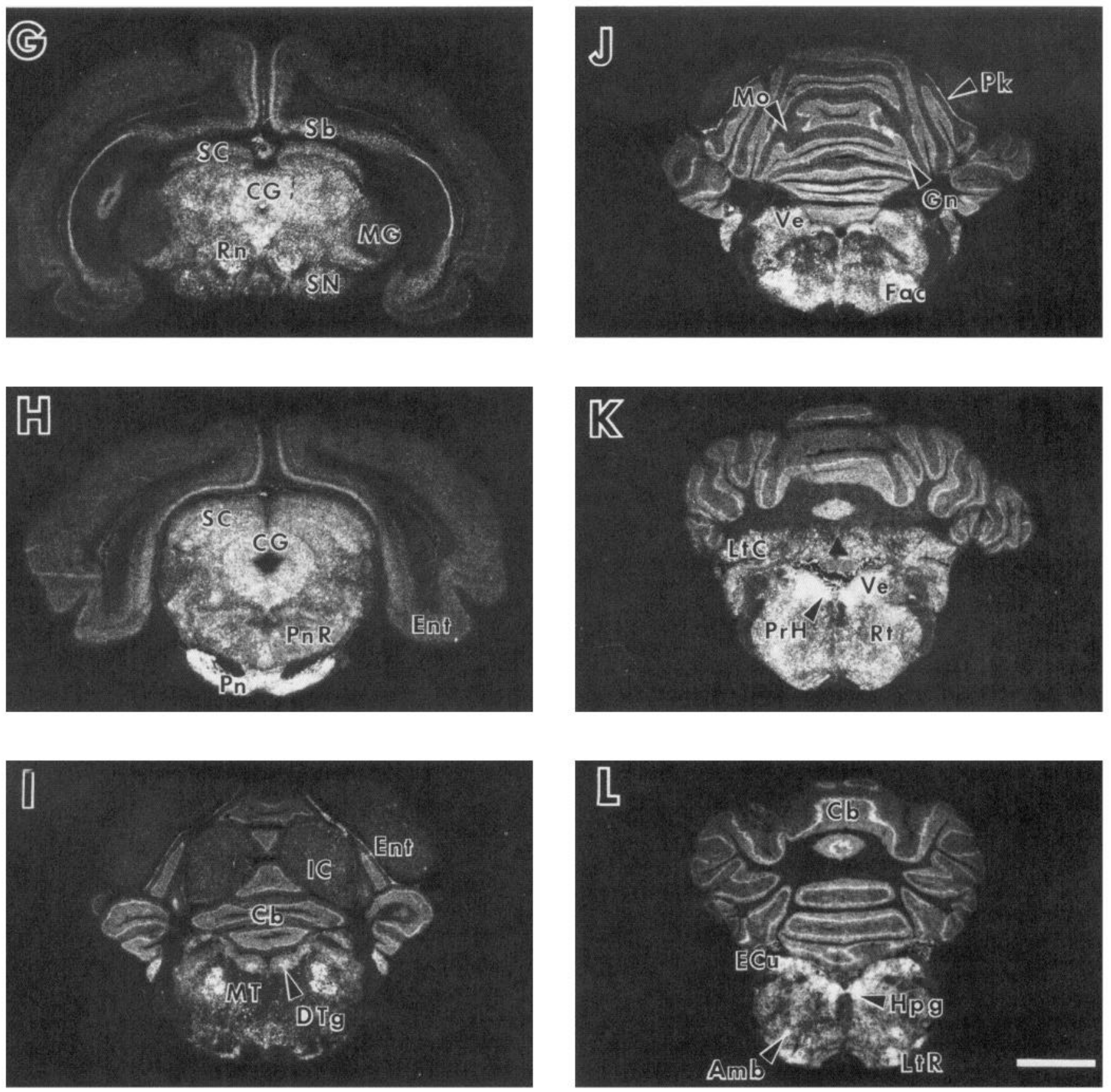

granule cell layer, cerebellum; $G P$, globus pallidus; $H b$, habenula; $H p g$, hypoglossal n.; $I C$, inferior colliculus; $I N$, zona incerta; $L G$, lateral geniculate $\mathrm{n}$.; $L M$, lateral mamillary $\mathrm{n}$; $L S$, lateral septal $\mathrm{n}$.; $L t C$, lateral cervical $\mathrm{n}$.; $L t R$, lateral reticular $\mathrm{n}$; $M G$, medial geniculate $\mathrm{n}$.; $M o$, molecular layer, cerebellum; $M P o$, median preoptic n.; $M S$, medial septal n.; $M T$, motor trigeminal n.; $O c$, optic chiasm; $P C g$, posterior cingulate cortex; $P k$, Purkinje cell layer, cerebellum; $P n$, pontine n.; $P n R$, pontine reticular n.; $P o$, preoptic area; $P O$, primary olfactory cortex; $P r H$, prepositus hypoglossal n.; $P y$, pyramidal cell layer, primary olfactory cortex; $R n$, red n.; $R t$, reticular $\mathrm{n}$.; $S b$, subiculum; $S C$, superior colliculus; $S N$, substantia nigra; $S O$, supraoptic hypothalamic n.; $S t$, striate cortex; $T R t$, reticular thalamic n.; $V e$, vestibular n.; $V D b$, ventral diagonal band of Broca; $V P$, ventroposterior thalamic area. Further details are given in the text. Calibration bar, $3 \mathrm{~mm}$.

Recently, we identified specific binding sites for $(+)^{3} \mathrm{H}-3-\mathrm{PPP}$ in brain (Largent et al., 1984). These apparently non-dopaminergic binding sites have a pharmacological profile and regional distribution essentially the same as putative sigma receptor sites labeled with $(+)^{3} \mathrm{H}-\mathrm{SKF} 10,047$ (Gundlach et al., 1985; Largent et al., in press; Martin et al., 1984; Tam, 1983, 1985). Preliminary autoradiographic studies revealed an association of $(+)^{3} \mathrm{H}-$ 3-PPP binding sites with limbic and motor areas (Largent et al., 1984). The present study describes in detail the distribution of these binding sites in guinea pig and rat CNS as determined by in vitro autoradiography in combination with selective neuronal lesions.

\section{Materials and Methods}

\section{Tissue preparation}

Male Hartley guinea pigs, 250-350 gm, or male Sprague-Dawley rats, 200-250 gm (Hilltop, Scottsdale, PA), were used in all studies. Animals 
Table 2. Regional distribution of $(+)^{3} \mathbf{H}-3-P P P$ binding sites in guinea pig CNS

\begin{tabular}{|c|c|c|c|}
\hline Region & $\begin{array}{l}\text { Binding } \\
\text { (fmol/mg protein) }\end{array}$ & Region & $\begin{array}{l}\text { Binding } \\
\text { (fmol/mg protein) }\end{array}$ \\
\hline Cortex & & Midbrain & \\
\hline Frontal & $85 \pm 8$ & Superior colliculus & $159 \pm 18$ \\
\hline Frontoparietal & $94 \pm 6$ & Inferior colliculus & $118 \pm 6$ \\
\hline Pyriform, pyramidal cell layer & $125 \pm 28$ & Red $\mathbf{n}$. & $291 \pm 10$ \\
\hline Entorhinal & $84 \pm 6$ & Substantia nigra & $172 \pm 6$ \\
\hline Cingulate & & Ventral tegmental area of Tsai & $160 \pm 6$ \\
\hline Anterior & $88 \pm 4$ & Interpeduncular $\mathbf{n}$. & $121 \pm 50$ \\
\hline Posterior & $190 \pm 6$ & Lateral tegmental $\mathbf{n}$. & $182 \pm 10$ \\
\hline Basal ganglia & & Dorsal tegmental n. & $207 \pm 10$ \\
\hline Caudate putamen & $73 \pm 4$ & Anterior pretectal area & $325 \pm 42$ \\
\hline Accumbens n.$^{a}$ & $70 \pm 2$ & Central gray & $268 \pm 44$ \\
\hline Globus pallidus & $77 \pm 3$ & Dorsal raphe $\mathrm{n}$. & $251 \pm 57$ \\
\hline Septal area & & Deep mesencephalic $n$. & $178 \pm 22$ \\
\hline Lateral septal $\mathrm{n}$. & $130 \pm 11$ & Cranial nerve nuclei & \\
\hline Medial septal n. & $223 \pm 15$ & Oculomotor n. (3) & $392 \pm 55$ \\
\hline Diagonal band of Broca & & Trigeminal motor n. (5) & $523 \pm 36$ \\
\hline Vertical limb & $221 \pm 22$ & Facial n. (7) & $802 \pm 45$ \\
\hline Horizontal limb & $143 \pm 20$ & Medial vestibular n. (8) & $275 \pm 15$ \\
\hline Septohypothalamic $\mathbf{n}$. & $217 \pm 40$ & Superior vestibular n. (8) & $305 \pm 7$ \\
\hline Ventral pallidum & $138 \pm 14$ & Dorsal motor and solitary n. (10) & $240 \pm 18$ \\
\hline Septofimbrial $\mathbf{n}$. & $116 \pm 15$ & Ambiguus n. (10) & $301 \pm 40$ \\
\hline Bed nucleus stria terminalis & $195 \pm 48$ & Hypoglossal n. (12) & $784 \pm 43$ \\
\hline Hippocampal formation & & Pons & \\
\hline Stratum pyramidale & $144 \pm 50$ & Pontine central gray & $245 \pm 15$ \\
\hline Stratum radiatum & $46 \pm 10$ & Pontine reticular $\mathbf{n}$. & $373 \pm 43$ \\
\hline Dentate gyrus, granular layer & $126 \pm 14$ & Pontine area & $162 \pm 56$ \\
\hline Subiculum & $144 \pm 6$ & Reticulotegmental $\mathrm{n}$. & $376 \pm 26$ \\
\hline Amygdala & & Locus coeruleus & $241 \pm 36$ \\
\hline & & Cuneiform $\mathbf{n}$. & $262 \pm 28$ \\
\hline $\begin{array}{l}\text { Central n. } \\
\text { Medial n. }\end{array}$ & $107 \pm 16$ & Gigantocellular reticular $\mathbf{n}$. & $242 \pm 7$ \\
\hline Medial n. & $108 \pm 14$ & Paragigantocellular reticular $\mathrm{n}$. & $251 \pm 23$ \\
\hline Anterior cortical $\mathbf{n}$. & $98 \pm 10$ & Ventral parabrachial $\mathbf{n}$. & $291 \pm 10$ \\
\hline Thalamus & & Dorsal parabrachial n. & $201 \pm 9$ \\
\hline Habenular $\mathrm{n}$. & $184 \pm 9$ & Medulla & \\
\hline Medial geniculate $\mathbf{n}$. & $93 \pm 4$ & Prepositus hypoglossal $\mathbf{n}$. & $520 \pm 18$ \\
\hline Lateral geniculate $\mathbf{n}$. & $100 \pm 5$ & Deep cochlear $\mathbf{n}$. & $126 \pm 30$ \\
\hline Reticular n. & $206 \pm 7$ & Ventral cochlear $n$. & $250 \pm 40$ \\
\hline Anteromedial $\mathrm{n}$. & $123 \pm 3$ & External cuneate $n$. & $319 \pm 10$ \\
\hline Ventral thalamic $n$. & $76 \pm 7$ & Parvocellular reticular $\mathrm{n}$. & $171 \pm 41$ \\
\hline Zona incerta & $155 \pm 4$ & Cerebellum & \\
\hline Hypothalamus & & Purkinje layer & $330 \pm 18$ \\
\hline Anterior hypothalamic area & $182 \pm 40$ & Molecular layer & $104 \pm 7$ \\
\hline Paraventricular $\mathbf{n}$. & $150 \pm 24$ & Granular layer & $191 \pm 17$ \\
\hline Lateral preoptic area & $161 \pm 11$ & Interpositus cerebellar $\mathbf{n}$. & $134 \pm 13$ \\
\hline Medial preoptic area & $221 \pm 52$ & Spinal cord & \\
\hline Supraoptic n. & $221 \pm 45$ & Ventral horn ${ }^{b}$ & \\
\hline Mamillary $\mathbf{n}$. & $\begin{array}{l}107 \pm 10 \\
160+15\end{array}$ & Cervical & $965 \pm 95$ \\
\hline Lateral mamillary $\mathbf{n}$. & $\begin{array}{l}160 \pm 15 \\
134+15\end{array}$ & Thoracic & $895 \pm 58$ \\
\hline Medial forebrain bundle & $134 \pm 15$ & Lumbar & $618 \pm 88$ \\
\hline
\end{tabular}


Table 2. Continued

\begin{tabular}{llll} 
Region & $\begin{array}{l}\text { Binding } \\
(\mathrm{fmol} / \mathrm{mg} \text { protein) }\end{array}$ & Region & $\begin{array}{l}\text { Binding } \\
(\mathrm{fmol} / \mathrm{mg} \text { protein) }\end{array}$ \\
\hline $\begin{array}{l}\text { Dorsal horn } \\
\text { Cervical }\end{array}$ & $164 \pm 8$ & White matter tracts & $30 \pm 12$ \\
Thoracic & $207 \pm 45$ & Corpus callosum & $40 \pm 3$ \\
Lumbar & $100 \pm 25$ & Anterior commissure & $32 \pm 6$ \\
Spinal root ganglion & & Fornix & $32 \pm 8$ \\
Dorsal & $1172 \pm 190$ & Optic tract & $38 \pm 4$ \\
$\quad$ Ventral & $1198 \pm 138$ & Spinal white matter &
\end{tabular}

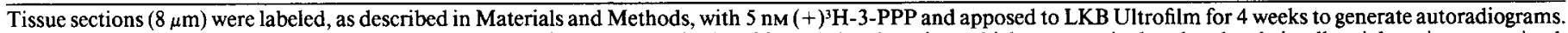

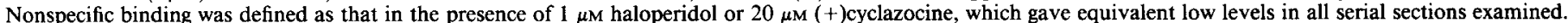

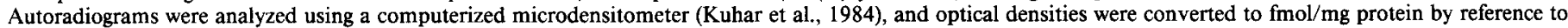

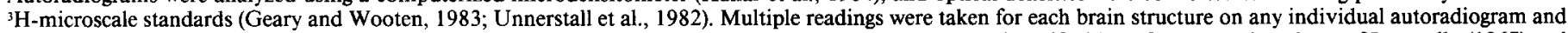

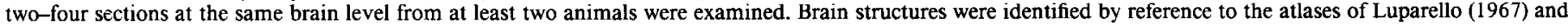
Paxinos and Watson (1982).

a . = nucleus or nuclei.

${ }^{b}$ Values represent densities over large cells in ventral horn.

$\leftarrow$ Values represent densities for overall gray matter.

were anesthetized with sodium pentobarbital and perfused via the left cardiac ventricle or aorta with $200 \mathrm{ml} 50 \mathrm{~mm}$ sodium phosphate, $\mathrm{pH}$ 7.5 , containing $100 \mathrm{~mm} \mathrm{NaCl}$, followed by $200 \mathrm{ml} 50 \mathrm{~mm}$ sodium phosphate, $\mathrm{pH} 7.5$, containing $0.3 \mathrm{~m}$ sucrose. After decapitation, brains and/or spinal cords were removed and mounted in a 1:1 mixture of bovine brain paste: Tissue-tek (Miles Laboratories, Naperville, IL) in plastic embedding molds and frozen rapidly on dry ice-ethanol. At this stage, tissues were stored at $-20^{\circ} \mathrm{C}$. Tissues were mounted on microtome chucks, and 8 or $12 \mu \mathrm{m}$ sections were cut at $-18^{\circ} \mathrm{C}$ and thaw-mounted on gelatin/chrome alum-coated slides. Brain sections were stored at $-20^{\circ} \mathrm{C}$ until use.

\section{Autoradiography}

Tissue sections were warmed to room temperature and washed in 50 mM Tris- $\mathrm{HCl}$ buffer, $\mathrm{pH} 8.0$ (incubation buffer), for a $15 \mathrm{~min}$ preincubation period at $22-25^{\circ} \mathrm{C}$. In routine experiments, slides were drained and transferred to the incubation mixture in $50 \mathrm{ml}$ coplin jars. Brain sections were incubated in buffer containing 4-5 nM (+) ${ }^{3} \mathrm{H}-3-\mathrm{PPP}$ for $45 \mathrm{~min}$ at $22-25^{\circ} \mathrm{C}$. Nonspecific binding was determined by inclusion of $1 \mu \mathrm{M}$ haloperidol or $20 \mu \mathrm{M}(+)$ cyclazocine in the incubation buffer. For drug-inhibition studies, brain sections after preincubation were dried on a slide-warmer set at $30^{\circ} \mathrm{C}$ and then covered with $300-500 \mu \mathrm{l}$ of incubation buffer containing 4-5 $\mathrm{nM}(+)^{3} \mathrm{H}-3-\mathrm{PPP}$ and various concentrations of drug for $45 \mathrm{~min}$ at $22-25^{\circ} \mathrm{C}$. Following incubation, slides were dipped $(1-2 \mathrm{sec})$ and then washed $(2 \times 4 \mathrm{~min})$ in buffer, rinsed in distilled water, and dried under a stream of cold dry air and then on a slide-warmer $\left(30^{\circ} \mathrm{C}\right)$. Brain sections were then either removed with glass fiber filter disks and their radioactivity content estimated by scintillation spectrometry or apposed to tritium-sensitive Ultrofilm (LKB, Gaithersburg, MD) at $4^{\circ} \mathrm{C}$ for $4-10$ weeks to generate autoradiograms.

\section{Data analysis}

After the appropriate time of exposure, Ultrofilm was developed and fixed using Kodak D-19 developer and Rapid Fixer. Densitometric analysis of $(t)^{3} \mathrm{H}-3-\mathrm{PPP}$ binding was performed using a computerized microdensitometer (Loats Associates, Westminster, MD; Kuhar et al, 1984) with optical densities converted to $\mathrm{fmol} / \mathrm{mg}$ protein using a standard scale based on tritium-methacrylate microscales (Amersham, Chicago, IL; Geary and Wooten, 1983) exposed to each film. Data from drug-inhibition experiments were analyzed using the EBDA curve-fitting computer program (McPherson, 1983).

\section{Lesion studies}

Selective neuronal lesions in different brain areas were made using various neurotoxins. Male Sprague-Dawley rats (200-250 gm) were anesthetized by intraperitoneal injection of chloral hydrate $(400 \mathrm{mg} / \mathrm{kg})$ or sodium pentobarbital $(65 \mathrm{mg} / \mathrm{kg}$ ) and placed in a stereotaxic frame (Kopf
Instruments, Tujunga, CA). Injection-site coordinates were determined using the atlas of Paxinos and Watson (1982) and confirmed by dye injection in age-matched controls or by histological examination during sectioning for autoradiographic studies.

Quinolinic, ibotenic, and kainic acids were dissolved in $0.9 \% \mathrm{NaCl}$ and adjusted to $\mathrm{pH} 7.4$ with $0.1 \mathrm{M} \mathrm{NaOH}$. 6-Hydroxydopamine was dissolved in a $1 \mathrm{mg} / \mathrm{ml}$ ascorbic acid solution. Toxins were administered into the desired brain area in a volume of $1-2 \mu 1$ with a Hamilton microsyringe over 1-2 min. Lesioned animals were sacrificed at the appropriate time following treatment. The extent and selectivity of lesions was determined by histological examination of brain sections with toluidine blue, acetylcholinesterase, and silver stains (Ralis et al., 1973). Quinolinic acid (200 nmol) was used to lesion the hippocampal formation (Schwarcz et al., 1983). Ibotenic acid (100 nmol) or 6-hydroxydopamine $(100 \mathrm{nmol})$ was microinjected unilaterally into the corpus striatum to lesion intrinsic neurons or dopaminergic neurons, respectively (Schwarcz et al., 1979; Ungerstedt, 1971). Autoradiography was performed as described and densitometric analysis was used to determine the quantitative regional effects of the lesions on $(+)^{3} \mathrm{H}-3-$ PPP binding.

\section{Materials}

$(+)^{3} \mathrm{H}-3-P P P(107.4 \mathrm{Ci} / \mathrm{mmol})$ was kindly provided by New England Nuclear Corporation (Boston, MA). (+)3-PPP was generously donated by Astra Laboratories (Sodertalje, Sweden). Drugs and their sources were as follows: haloperidol, McNeil Pharmaceutical (Spring House, PA); $(+)$ and ( )butaclamol, Rescarch Biochemicals International (Wayland, MA); ( \pm )pentazocine and $(+),(-)$ cyclazocine, Sterling Winthrop Research Institute (Rensselaer, NY). Quinolinic acid and 6-hydroxydopamine were purchased from Sigma Chemical Company (St. Louis, MO), and ibotenic acid was obtained from Regis Chemical Company (Morton Grove, IL).

\section{Results}

General characteristics of $(+)^{3} \mathrm{H}-3-\mathrm{PPP}$ binding to brain sections

Before attempting autoradiographic localization of $(+)^{3} \mathrm{H}-3-\mathrm{PPP}$ binding sites, it was necessary to establish that binding sites labcled with $(+)^{3} \mathrm{H}-3$-PPP in slide-mounted brain sections have similar properties to those in tissue homogenates (Table 1). In brain sections, $(+)^{3} \mathrm{H}-3-\mathrm{PPP}$ binding at $25^{\circ} \mathrm{C}$ is time-dependent, with a plateau in binding attained within $45 \mathrm{~min}$, the incubation period employed routinely for autoradiographic studies. $(+)^{3} \mathrm{H}-$ 3-PPP binding to brain sections is saturable with a single component of binding evident by Scatchard analysis. The dissocia- 

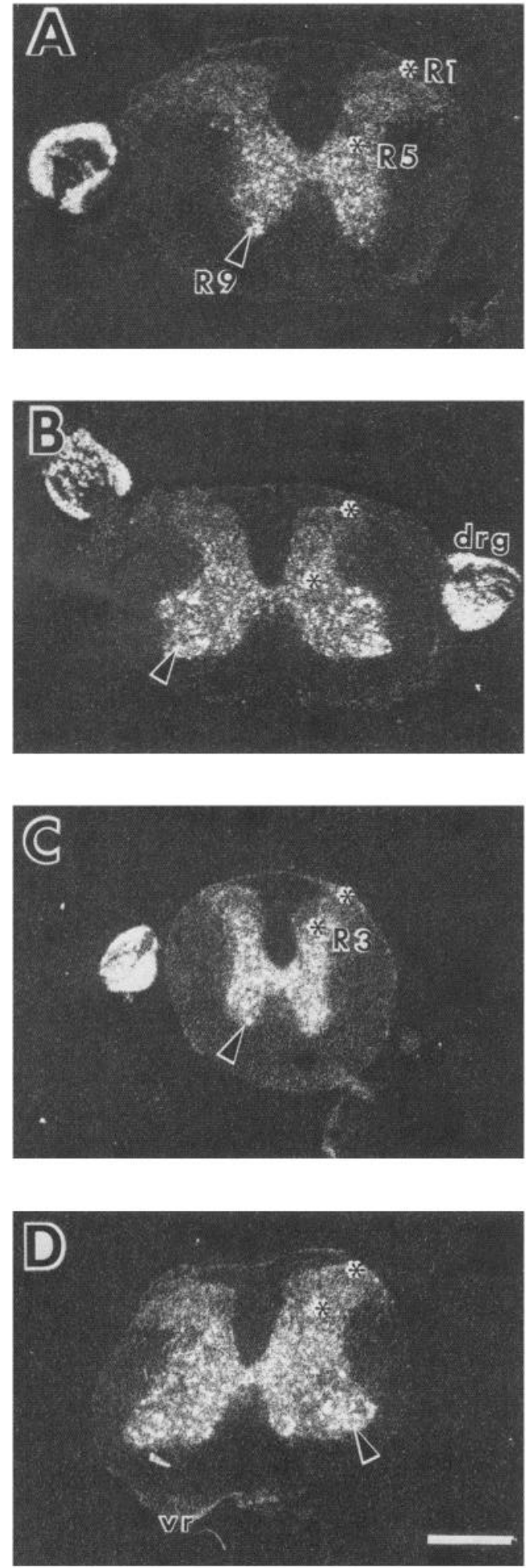

Figure 2. Autoradiograms of $(+)^{3} \mathrm{H}-3-\mathrm{PPP}$ binding sites in guinea pig spinal cord. Sections are shown at the level of upper $(A)$ and lower $(B)$ cervical, thoracic $(C)$, and lumbar $(D)$ spinal cord. Note the high density of $(+)^{3} \mathrm{H}$-3-PPP-associated silver grains over the large cells in the ventral root $(v r)$ a gray matter, particularly the ninth layer of Rexed $(R 9 ; a r-$ rowheads) and dorsal root ganglia ( $d r g)$ at all levels of the cord. Binding is lower in the dorsal horn in layers of Rexed 1-5 in upper and lower cervical, and layers $1-3$ in thoracic and lumbar $(R 1,3,5$; asterisks $)$ spinal cord. Further details are given in legend to Figure 1 and in Results. Calibration bar, $1 \mathrm{~mm}$. tion constant $\left(K_{\mathrm{d}}\right)$ is $30 \mathrm{nM}$, similar to values obtained in brain homogenates (Largent et al., 1984). The estimated maximal number of binding sites $\left(B_{\max }\right)$ is $100-150 \mathrm{fmol} / 12 \mu \mathrm{m}$ sagittal section, consistent with levels found in brain homogenates.

The drug specificity of $(+)^{3} \mathrm{H}-3-P P P$ binding in brain sections is also similar to that of homogenates. The most potent inhibitor of binding is haloperidol $\left(\mathrm{IC}_{50}=5 \mathrm{nM}\right)$. As in homogenates, the stereospecificity for opioids is opposite to that of conventional opiate receptors, with the (+)isomer of cyclazocine being $10 \times$ more potent than the (-)isomer. While 3-PPP displays pharmacologic activity at dopamine receptors (see introduction), $(+)^{3} \mathrm{H}-3$-PPP binding in brain sections, as well as homogenates, shows a stereospecificity opposite to that observed at dopamine receptors for the neuroleptic butaclamol, with the (-)isomer $50 \times$ more potent than the $(+)$ isomer.

\section{Autoradiographic localizations of $(+)^{3} \mathrm{H}-3-P P P$ binding sites in guinea pig CNS}

Discrete localizations of $(+)^{3} \mathrm{H}-3$-PPP binding sites are observed throughout the guinea pig CNS, confirming and extending our earlier observations (Largent et al., 1984)-see Figures 1 and 2 and Table 2 . In the cerebral cortex, intense binding is associated with the pyramidal cell layers, especially in the pyriform (or primary olfactory) cortex (Fig. 1, $A-D$ ). Superficial layers in the cingulate, anterior and posterior (Fig. 1, $B-F$ ), and retrosplenial (Fig. 1, $G-H$ ) cortices are also heavily labeled. In contrast to the distribution of dopamine receptors, relatively little binding is observed in the caudate-putamen (Fig. 1, B-D), although moderate levels are present in the ventral pallidum and the globus pallidus (Fig. 1D). In the hypothalamus and related areas, the medial preoptic, preoptic, supraoptic, and paraventricular nuclei are intensely labeled (Fig. 1D), as are the lateral mamillary bodies (Fig. $1 E$ ). However, receptor labeling is not uniform throughout the hypothalamus, as more medially the mamillary bodies are almost devoid of autoradiographic grains. Most of the thalamus is poorly labeled, with the ventral posterior nucleus being nearly devoid of grains (Fig. $1 E$ ). By contrast, substantial binding occurs in the lateral reticular nucleus of the thalamus as well as the zona incerta of the subthalamus. The choroid plexus is also heavily labeled by $(+)^{3} \mathrm{H}-$ 3-PPP (Fig. 1D).

Many structures associated with the limbic system are heavily labeled. For instance, the lateral septal nucleus has a high grain density, as do the medial septal area, the diagonal band, and parts of the hippocampus. Within the hippocampus, grain densities are restricted to the pyramidal cell layers (CA1-4) and the granular layer of the dentate gyrus (Fig. 1, $E, F$ ). The central gray of the midbrain is intensely labeled, and moderate binding occurs in the subiculum (Fig. $1, F-H$ ).

Within the hindbrain, intense punctate binding is seen over cranial nerve nuclei, including the hypoglossal, vestibular, facial, abducens, trochlear, and oculomotor nuclei, the motor nucleus of the trigeminal nerve, motor nucleus of the vagus, and the nucleus ambiguus (Fig. 1, $G-L$ ). Other brain stem areas with high levels of binding include the red nucleus, the pontine nuclei, the pontine and medullary reticular formation, and the superior colliculus.

The cerebellum displays a discrete band of labeling associated with the Purkinje cell layer (Fig. 1, $F-L$ ). A substantial grain density overlies the granule cell layer; this contrasts with the molecular layer, which has low binding levels. Moderate grain densities occur in some of the deep cerebellar nuclei, such as the lateral cervical nucleus.

In spinal cord, the highest concentrations of grains occur in the dorsal root ganglia at all levels examined (Fig. 2). In most sections the grains appear concentrated in the peripheral zone, with the central portion of the ganglion, containing fibers of passage, displaying fewer grains (see below). Radiographic grains 
Table 3. Effect of neurotoxin lesions on the amount of $(+)^{3} \mathrm{H}-3-\mathrm{PPP}$ binding in selected brain regions

\begin{tabular}{lllc} 
Lesioned area & Toxin & Structure examined & $\begin{array}{c}\text { Decrease in } \\
(+)^{3} \mathbf{H}-3-P P P \\
\text { binding (\%) }\end{array}$ \\
\hline Hippocampus $^{a}$ & Quinolinic acid & $\begin{array}{l}\text { Pyramidal cell layer } \\
\text { Dentate gyrus granular layer }\end{array}$ & $85 \pm 3^{* *}$ \\
Striatum & Ibotenic acid & Striatum & $82 \pm 3^{* *}$ \\
& & Substantia nigra & $68 \pm 7^{* *}$ \\
Striatum & 6-OHDA & Striatum & $8 \pm 2^{*}$ \\
& & Substantia nigra & $17+4^{*}$ \\
& & Pars compacta & $32 \pm 2^{* *}$
\end{tabular}

Lesions were produced in the indicated areas with the respective neurotoxins, as described in Materials and Methods, and animals were sacrificed $4 \mathrm{~d}$ (hippocampus) or $14 \mathrm{~d}$ (striatum) later. The effect of the lesion was evaluated in the ipsilateral region of interest and compared with the contralateral control region. Lesion effects were evaluated in at least four-eight brain sections from each of two to three animals and quantitated from the autoradiogram. Data are reported as the percentage decrease $( \pm S E M)$ in $(+)^{3} \mathrm{H}-3-P P P$ binding due to the lesion, relative to control, and are significantly different from control by at lcast ${ }^{*} p<0.005$ or ${ }^{* *} p<0.001$ (one-tailed Student's $t$ test).

"No significant change occurred in the amount of binding in the stratum radiatum.

are associated exclusively with gray matter areas throughout the spinal cord and are more dense in the ventral than the dorsal horn.

\section{Autoradiographic localizations of $(+)^{3} \mathrm{H}-3-\mathrm{PPP}$ binding sites in rat CNS}

As marked species differences in receptor binding sites for a variety of ligands have been described, we also examined the localization of $(+)^{3} \mathrm{H}-3$-PPP binding sites in the rat CNS (Fig. 3). Localizations are closely similar in rat and guinea pig CNS, with only quantitative differences between the two species. Very high grain densities occur over motor nuclei, such as the motor nucleus of the trigeminal nerve, and facial and hypoglossal nuclei (Fig. 3, $H-K$ ), as in the guinea pig. In the hippocampus of the rat, as in the guinca pig, grain densities are most concentrated in the pyramidal cell layer (Fig. 3, $D-F$ ). While the guinea pig has high levels of receptors in the Purkinje cell layer of the cerebellum (see below), relatively less binding is apparent in the rat cerebellum. However, the limited amount of binding appears primarily associated with the Purkinje and granule cell layers (Fig. 3, $H-K$ ). In the rat brain stem, pontine and reticular nuclei display lower $(+)^{3} \mathrm{H}-3-P P P$ binding relative to the intense labeling of these areas in the guinea pig. The distribution of $(+)^{3} \mathrm{H}-$ 3-PPP-associated grain densities in the spinal cord of the rat is similar to that seen in the guinea pig (Fig. $3 L$ ).

\section{Cellular localization of $(+)^{3} \mathrm{H}-3-P P P$ binding sites}

The cellular localization of receptor binding sites was further investigated by histological examination of specific areas of guinea pig and rat brain under high-power magnification and comparison with the corresponding autoradiographic grain distributions. In all areas examined (i.e., the hippocampus, cerebellum, and brain stem), grains appear localized exclusively to neuronal cell bodies (Figs. 4 and 5 ). In the guinea pig cerebellum, the highest concentration of $(+)^{3}$ H-3-PPP binding is over the Purkinje cell layer, with moderate to low concentrations associated with the granule cell and molecular layers, respectively (Fig. $4 B$ ). The spinal cord displays grains primarily over large motor neurons in the ventral horn. In dorsal root ganglia, $(+)^{3} \mathrm{H}-3-$ PPP binding is associated with the sensory cells and not with the white matter tracts passing through the ganglion (Fig. 4D). The binding is so intense that, even with coverslips, it is difficult to differentiate between the sensory and satellite cells. Given the association of $(+)^{3} \mathrm{H}-3$-PPP binding with gray matter regions elsewhere in the brain, binding is likely to be to the sensory cells (see below). $(+)^{3} \mathrm{H}-3$-PPP binding in all the cranial nerve nuclei selectively overlies large motor cells, for example, the hypoglossal (Fig. $5 A$ ), ambiguus (Fig. $5 B$ ), and facial (Fig. $5 D$ ) nuclei. Radiographic grains in the hippocampus are selectively associated with pyramidal cells and the granule cells of the dentate gyrus (Fig. 6), whilc, in the pars compacta of the substantia nigra, receptors appear localized to dopamine neuron cell bodies (see below).

\section{Effects of neurotoxin lesions on $(+)^{3} H-3-P P P$ binding sites in rat brain}

The selective association of autoradiographic grains with neuronal cell bodies in many brain regions suggests that receptors are primarily localized to neuronal cells. However, grains could be localized also to nerve terminals synapsing on neuronal soma. Accordingly, selective lesions of intrinsic neurons were employed to investigate this possibility. In the hippocampus, quinolinic acid lesions abolish autoradiographic grains over the pyramidal cell layer of the hippocampus and the granule cell layer of the dentate gyrus (Fig. 6, Table 3). The loss of binding in hippocampal pyramidal cell layers with quinolinic acid treatment strongly suggests that receptors are selectively associated with the pyramidal cells. Furthermore, lesions of the entorhinal cortex and lateral septum, both sources of major neuronal projections to the hippocampus, produce no change in grain patterns in the hippocampus. Thus, within the hippocampus, grains appear to be primarily, if not exclusively, associated with pyramidal cells. In a single animal, kainic acid injected into the cerebellum depleted receptor binding associated with the granule and Purkinje cell layers by about $50 \%$, with no effect on the low levels of binding to the molecular layer (data not shown).

To evaluate $(+)^{3} \mathrm{H}-3$-PPP-associated grain localizations in the striatonigral system, either ibotenic acid or 6-hydroxydopamine was administered into the corpus striatum to lesion intrinsic neurons or dopaminergic afferents, respectively. Both the corpus striatum and substantia nigra were examined in each lesioned animal for changes in $(+)^{3} \mathrm{H}-3-P P P$ binding (Table 3 ). Ibotenic acid administered into the corpus striatum substantially depleted striatal autoradiographic grains with a much smaller effect on binding in the substantia nigra, suggesting an association of striatal $(+)^{3} \mathrm{H}-3-\mathrm{PPP}$ binding primarily with intrinsic neurons that do not project to the substantia nigra.

Striatal injection of 6-hydroxydopamine, which destroys dopamine nerve terminals in the corpus striatum and produces a retrograde degeneration of dopamine containing cells in the pars compacta of the substantia nigra, significantly depleted $(+)^{3} \mathrm{H}-$ 3-PPP binding in the ipsilateral pars compacta of the substantia 

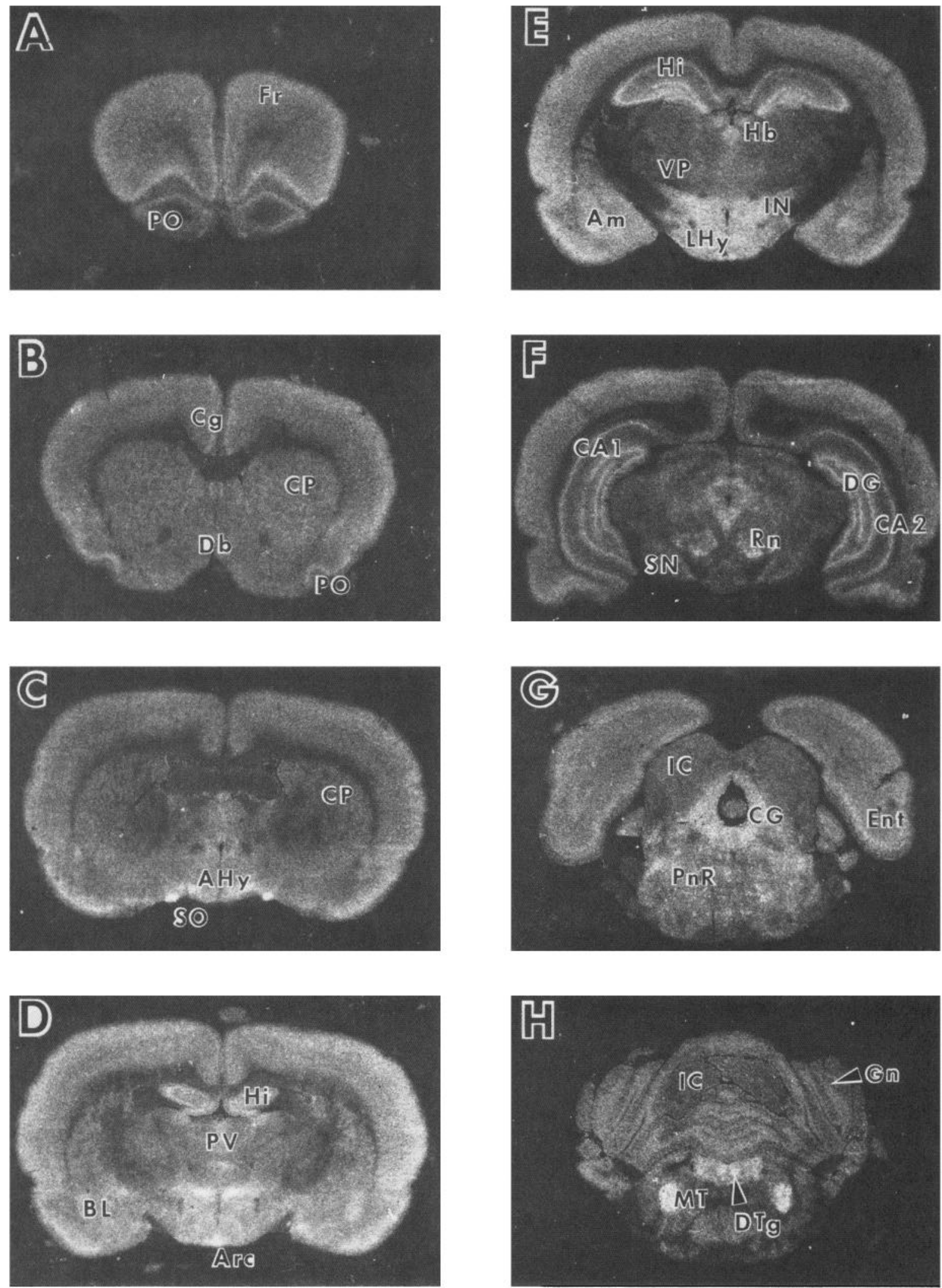

Figure 3. Autoradiograms of $(+)^{3} \mathrm{H}-3-\mathrm{PPP}$ binding in rat brain and spinal cord. Representative sections are presented in a rostral-caudal progression for brain $(A-K)$ and for cervical and thoracic spinal cord $(L)$. Nonspecific binding of $(+)^{3} \mathrm{H}-3$-PPP in the presence of $1 \mu \mathrm{M}$ haloperidol is shown at a similar exposure $(M)$. Abbreviations are as in legend to Figure 1 and as follows: $A H y$, anterior hypothalamic area; $A m$, amygdala; $A r c$, arcuate $\mathrm{n}$.; $B L$, basolateral amygdaloid $\mathrm{n}$.; $\mathrm{Dh}$, dorsal horn, spinal cord; $H i$, hippocampus; $L C$, locus coeruleus; $L H y$, lateral hypothalamic area; $P V$, paraventricular thalamic $\mathrm{n}$.; $R M$, raphe magnus $\mathrm{n}$.; $R 9$, ninth layer of Rexed, spinal cord. Further details are given in the legend to Figure 1 and in the text. Calibration bar, $2 \mathrm{~mm}$. 

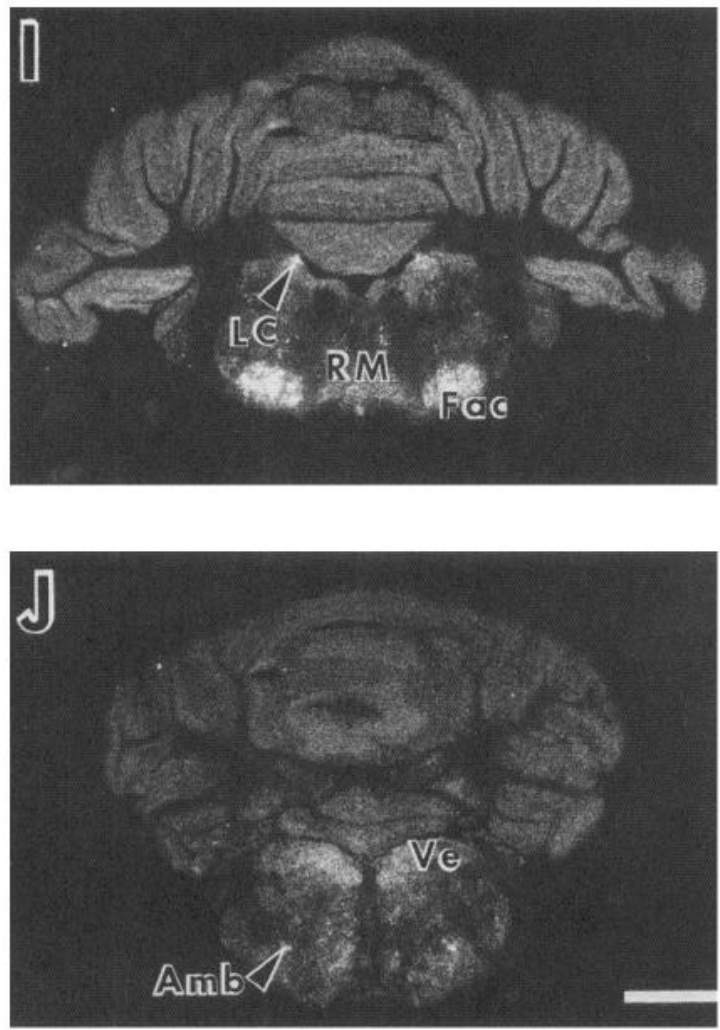

Figure 3. Continued.

nigra, with a relatively smaller loss of binding evident in the corpus striatum (Table 3 ). In the same animals, striatal ${ }^{3} \mathrm{H}$ mazindol binding, associated with dopamine uptake sites on dopaminergic nerve terminals (Javitch et al., 1985), is abolished, demonstrating the effectiveness of the lesion. This suggests that $(+)^{3} \mathrm{H}-3$-PPP binding is present on the cell bodies of dopamine containing neurons in the pars compacta of the substantia nigra and that a small portion of $(+)^{3} \mathrm{H}-3$-PPP binding $(\sim 20 \%)$ in the corpus striatum is present on dopaminergic terminals.

The possible association of sigma receptors with other biogenic amine systems was also investigated. Rats were treated with $p$-chloroamphetamine, which destroys serotonin neurons (Kohler et al., 1978; Neckers et al., 1976) and $N$-[2-chloroethyl]$N$-ethyl-2-bromobenzylamine (DSP-4), which selectively destroys norepinephrine-containing neurons (Hallman et al., 1984; Jonsson et al., 1981), and $(+)^{3} \mathrm{H}-3$-PPP binding was measured in whole-brain homogenates. Neither of these treatments markedly affected binding levels, despite their depletion of serotonin and norepinephrine concentrations, respectively, indicating significant lesions of these neuronal systems (data not shown).

\section{Discussion}

Binding sites for $(+)^{3} \mathrm{H}-3$-PPP in both guinea pig and rat CNS display very discrete localizations. While it is difficult to generalize about the type of structures labeled, the highest densities of radiographic grains appear to be associated with structures of the limbic system, cranial nerve motor and sensory nuclei, as well as reticular nuclei at all levels of the brain stem. Furthermore, the sensory dorsal root ganglia and the motor cells in the ventral horn of the spinal cord are heavily labeled. Highpower magnification studies of binding patterns indicate a selective localization of grains over neuronal cell bodies, a finding confirmed by a variety of lesion studies. Grain densities are highest in nuclei with large neuronal cells, such as the supraoptic
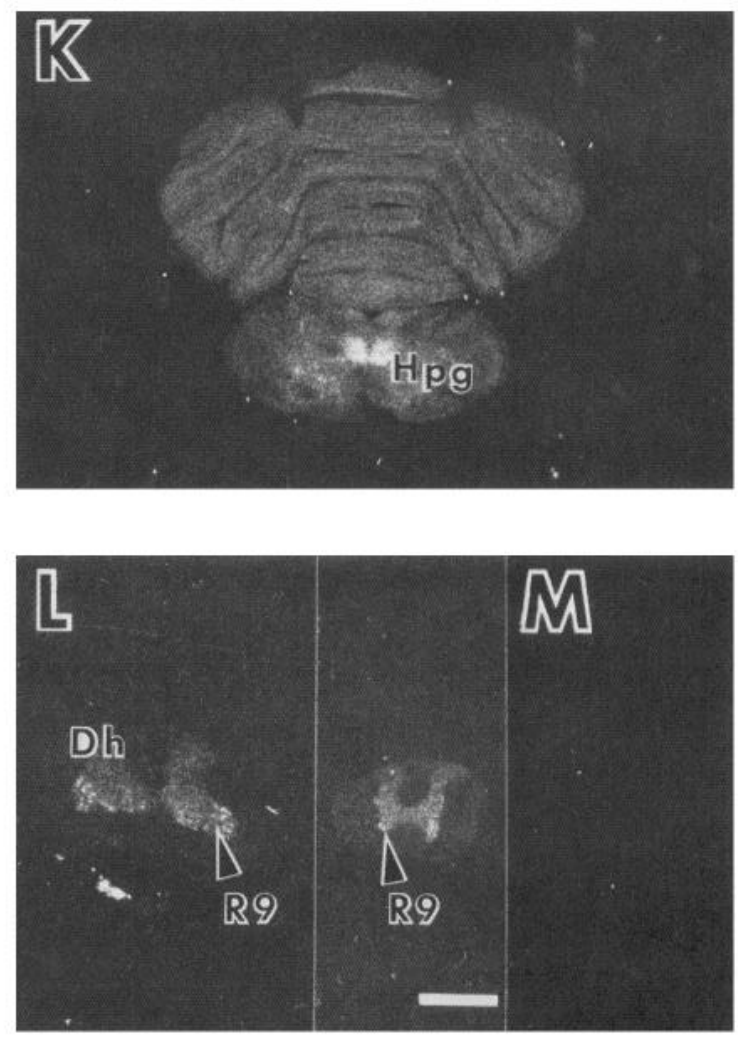

and paraventricular nuclei of the hypothalamus, the pyramidal cells of the hippocampus and cortex, and Purkinje cells of the cerebellum.

Previous studies (Gundlach et al., 1985; Largent et al., 1984, in press) revealed that the drug specificity of $(+)^{3} \mathrm{H}-3-\mathrm{PPP}$ binding sites is very similar to sigma receptor binding sites identified with $( \pm)$ and $(+)^{3} \mathrm{H}-\mathrm{SKF} 10,047,{ }^{3} \mathrm{H}$-haloperidol, and ${ }^{3} \mathrm{H}$ ethylketocyclazocine (Gundlach et al., 1985; Largent et al., 1984, in press; Su, 1981, 1982; Tam, 1985; Tam and Cook, 1984). Other studies have suggested that psychotomimetic opioids, such as $(+)^{3} \mathrm{H}-\mathrm{SKF} 10,047$, label binding sites resembling PCP receptors (Itzhak et al., 1985; Mendelsohn et al., 1985; Zukin et al., 1984) and differ from sigma sites. This discrepancy appears resolved by recent findings that $(+)^{3} \mathrm{H}-\mathrm{SKF} 10,047$ labels two binding-site populations (Gundlach et al., 1985; Largent et al., in press). The high-affinity sites have the pharmacological specificity of sigma binding sites as defined by their labeling with ${ }^{3} \mathrm{H}$-haloperidol and $(+)^{3} \mathrm{H}-3$-PPP, while the low-affinity sites represent PCP receptors. Thus, the binding sites examined in the present study are those defined as non-PCP sigma receptor binding sites.

Studies of the effects of 3-PPP in rodents suggest that the drug interacts with autoreceptors on dopamine neurons (Arnt et al., 1983; Hjorth et al., 1981, 1983, 1985). In the substantia nigra, sigma receptor binding sites appear localized to the dopaminecontaining cells of the pars compacta. Conceivably, the localization of sigma receptors in the nigra, as well as the cerebellum and other relevant regions, might relate to the effects of 3-PPP on locomotion. However, recent studies indicate that dopaminergic effects of 3-PPP are blocked by $(+)$ butaclamol but not by the (-)isomer (Hjorth et al., 1985), in contrast to the stereospecificity observed for butaclamol isomers at sigma receptors.

Whether the sigma binding sites are responsible for mediating 

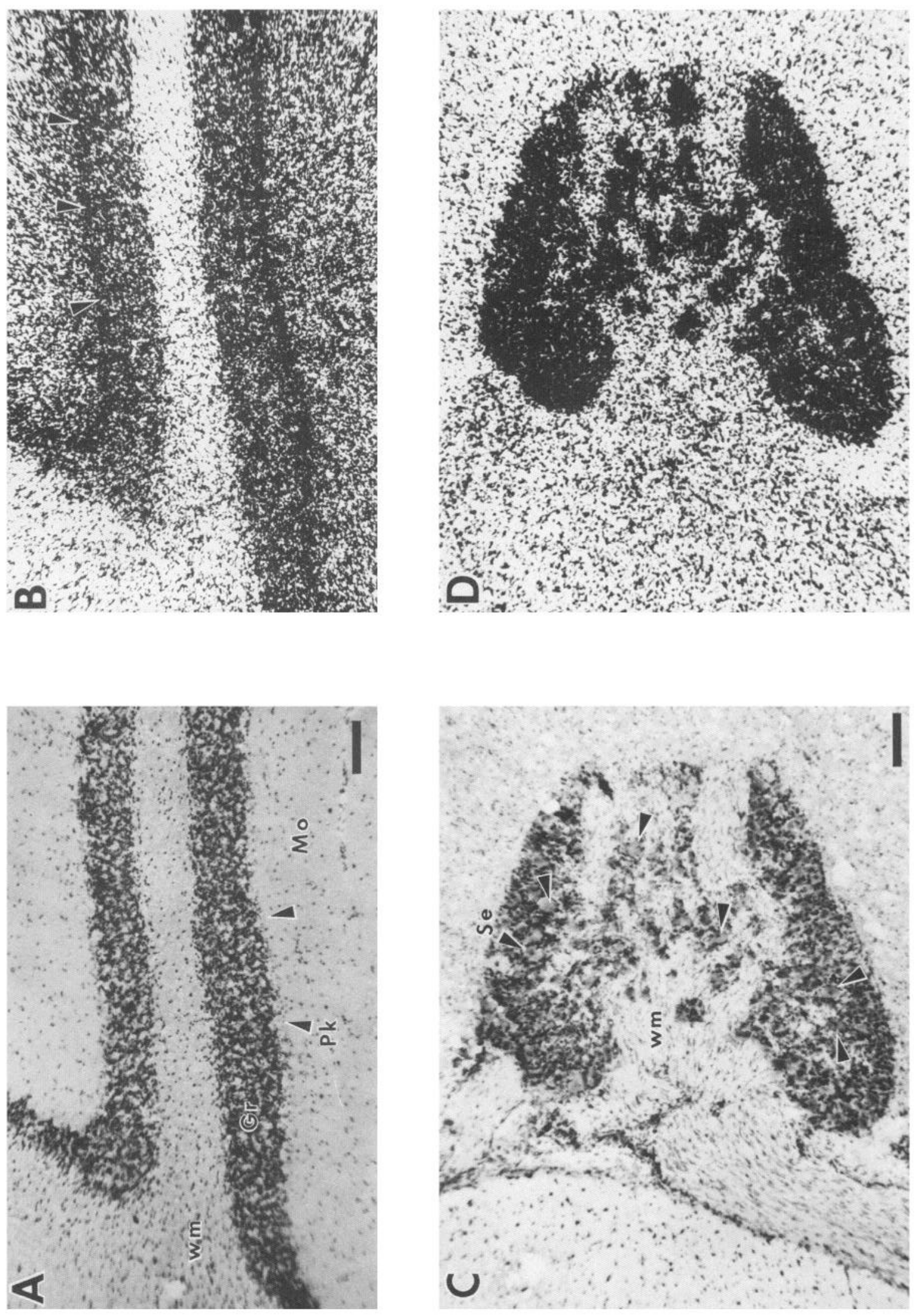

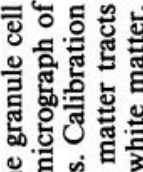

형

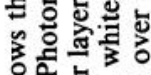

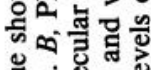

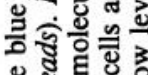

을

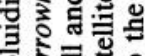

후웡요

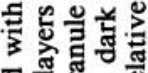

उ

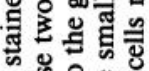

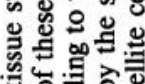

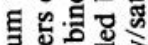

递要

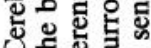

จ

ธี่

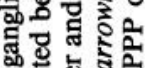

क

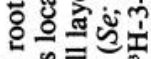

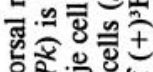

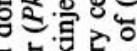

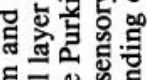

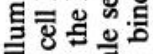

乎.

这客各要

을 के

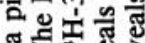

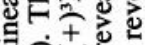

跑的

든 유응

氙

을응

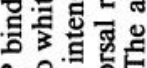

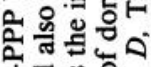

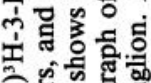

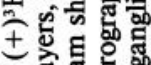

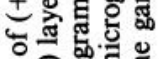

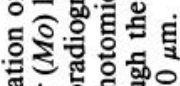

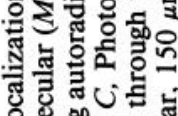

$\zeta$ 응

$\checkmark-0$ 웅.

矛实 

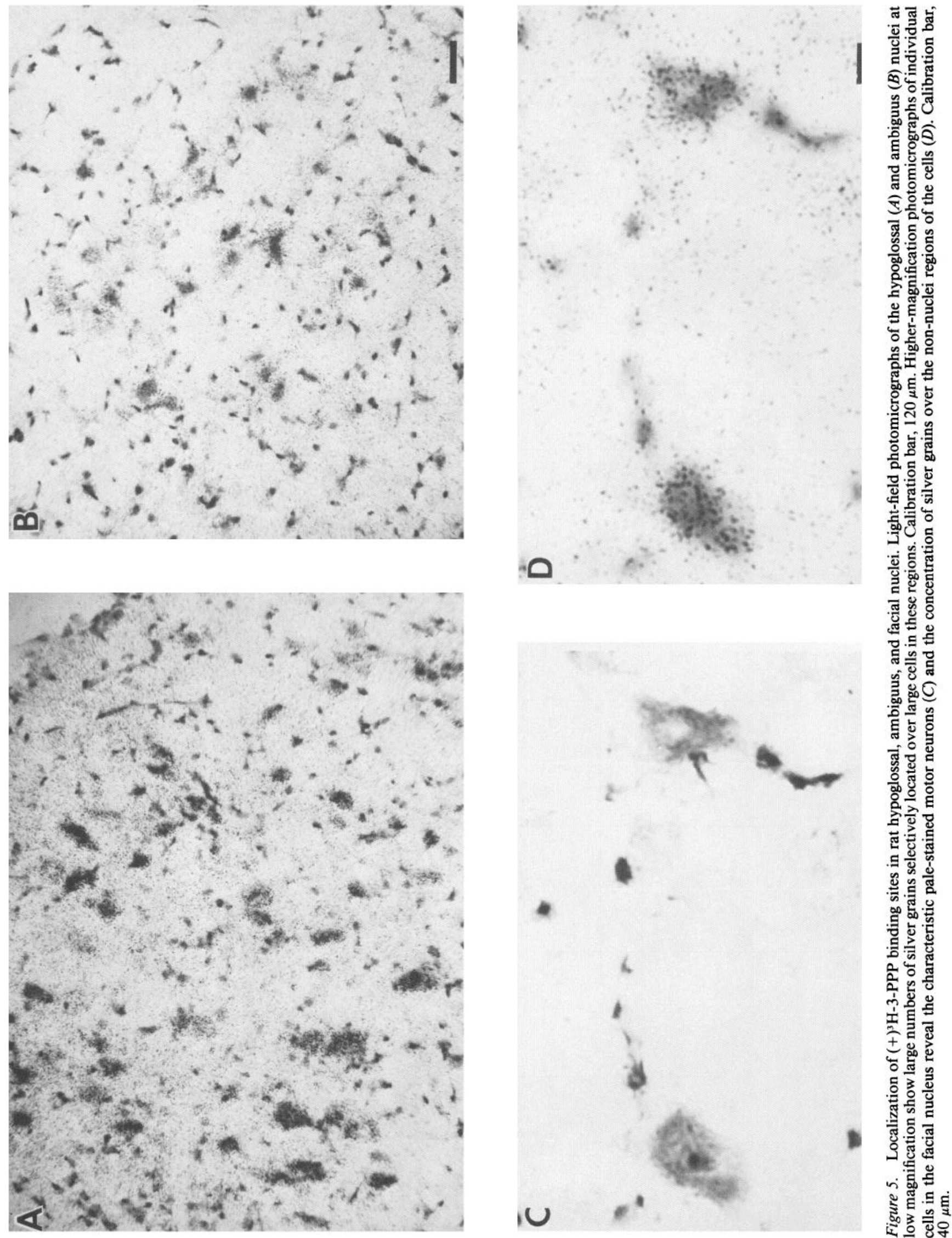

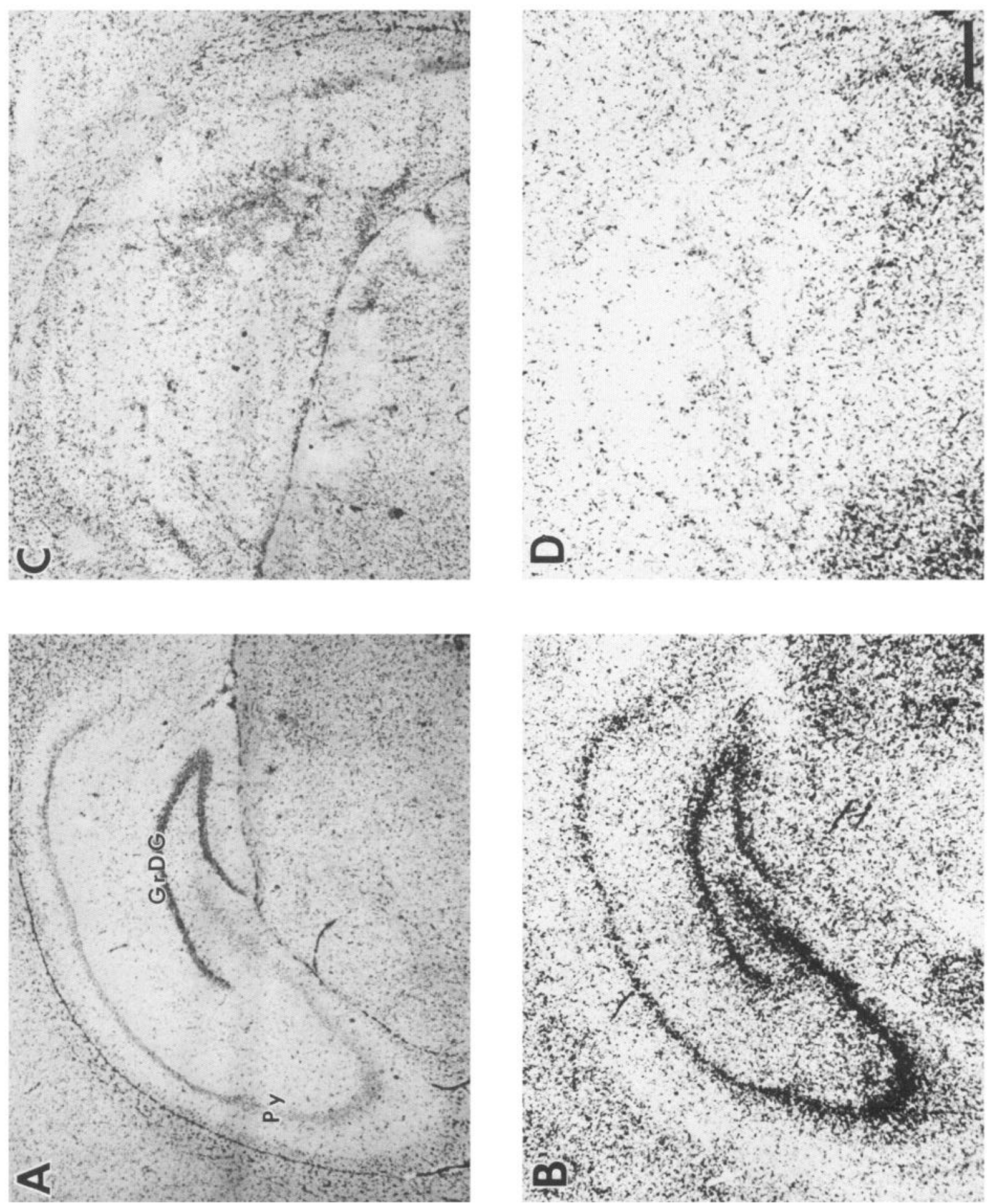

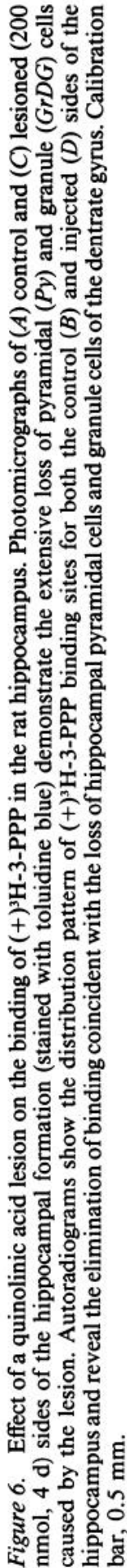


the sigma-like psychotomimetic effects of opioids is difficult to establish. Human data are limited, and it is unclear whether the behavioral effects of drugs in animals faithfully mimic those in humans. However, the sigma binding sites do show stereoselectivity for opioids, with the (+)isomer being more potent; this corresponds to the greater potency of the $(+)$ isomers of opioids in producing putative sigma-behavioral effects (Brady el al., 1982; Katz et al., 1985; Slifer and Balster, 1983). Recently, on the basis of autoradiographic results revealing sigma receptor binding sites on cerebellar Purkinje cells, the in vivo function of sigma receptors was investigated. Iontophoresis of (+)3-PPP onto cerebellar Purkinje cells decreases their spontaneous firing rate, an effect potently blocked by haloperidol and $(+) \mathrm{SKF}$ 10,047 , but only weakly by (-)SKF 10,047 (Lee et al., 1985). Moreover, the $(+)$ isomer of 3-PPP is more potent than the (-)isomer, similar to their relative potencies in vitro at sigma receptor binding sites. This in vivo effect of $(+) 3-P P P$ corresponds with the in vitro autoradiographic localization of sigma sites to cerebellar Purkinje cells and the pharmacological profile of sigma sites, thus suggesting that these in vivo inhibitory effects of $(+) 3$-PPP are mediated through sigma receptors.

\section{References}

Arnt, J., K. P. Bogeso, A. V. Christensen, J. Hyttel, J. J. Larsen, and O. Svendsen (1983) Dopamine receptor agonistic and antagonistic effects of 3-PPP enantiomers. Psychopharmacology 81: 199-207.

Brady, K. T., R. L. Balster, and E. L. May (1982) Discriminative stimulus properties of stereoisomers of $N$-allylnormetazocine in phencyclidine-trained squirrel monkeys and rats. Science 215: 178-180.

Geary, W. A., and G. F. Wooten (1983) Quantitative film autoradiography of opiate agonist and antagonist binding in rat brain. $J$. Pharmacol. Exp. Ther. 225: 234-240.

Gundlach, A. L., B. L. Largent, and S. H. Snyder (1985) Phencyclidine and sigma opiate receptors in brain: Biochemical and autoradiographical differentiation. Eur. J. Pharmacol. 113: 465-466.

Haertzen, C. A. (1970) Subjective effects of narcotic antagonists cyclazocine and nalorphine on the addiction research center inventory (ARCI). Psychopharmacologia 81: 366-377.

Hallman, H., E. Sundstrom, and G. Jonsson (1984) Effects of the noradrenaline neurotoxin DSP 4 on monoamine neurons and their transmitter turnover in rat CNS. J. Neural Transm. 60:89-102.

Haubrich, D. R., and A. B. Pflueger (1981) The autoreceptor control of dopamine synthesis. Mol. Pharmacol. 21:114-120.

Hjorth, S., A. Carlsson, H. Wikstrom, P. Lindberg, D. Sanchez, U. Hacksell, L. E. Arvidsson, U. Svensson, and J. L. G. Nilsson (1981) 3-PPP, a new centrally acting dopamine receptor agonist with selectivity for autoreceptors. Life Sci. 28: 1225-1238.

Hjorth, S., A. Carlsson, H. Wikstrom, P. Lindberg, D. Sanchez, U. Hacksell, L. E. Arvidsson, U. Svenson, and J. L. G. Nilsson (1983) Central dopamine receptor agonist and antagonist actions of the enantiomers of 3-PPP. Psychopharmacology 81: 89-99.

Hjorth, S., D. Clark, and A. Carlsson (1985) Lack of functional evidence for the involvement of sigma opiate receptors in the actions of the 3-PPP enantiomers on central dopaminergic systems: Discrepancies between in vitro and in vivo observations. Life Sci. 37: 673684.

Itzhak, Y., J. M. Hiller, and E. J. Simon (1985) Characterization of specific binding sites for $\left[{ }^{3} \mathrm{H}\right](d)-N$-allylnormetazocine in rat brain membranes. Mol. Pharmacol. 27: 46-52.

Iwamoto, E. T. (1981) Locomotor activity and antinociception after putative mu, kappa and sigma opioid receptor agonists in the rat: Influence of dopaminergic agonists and antagonists. J. Pharmacol. Exp. Ther. 217: 451-460.

Javitch, J. A., S. M. Strittmatter, and S. H. Snyder (1985) Differential visualization of dopamine and norepinephrine uptake sites in rat brain using $\left[{ }^{3} \mathrm{H}\right]$ mazindol autoradiography. J. Neurosci. 5: 1513-1521.

Jonsson, G., H. Hallman, F. Ponzio, and S. B. Ross (1981) DSP4 ( $N$ [2-chloroethyl]- $N$-ethyl-2-bromobenzylamine)-a useful denervation tool for central and peripheral noradrenaline neurons. Eur. J. Pharmacol. 72: 173-188.

Katz, J. L., R. D. Spealman, and R. D. Clark (1985) Stereoselective behavioral effects of $\mathrm{N}$-allylnormetazocine in pigeons and squirrel monkeys. J. Pharmol. Exp. Ther. 232: 452-461.

Keats, A. S., and J. Telford (1964) Narcotic antagonists as analgesics. Clinical aspects. In Molecular Modification in Drug Design. Advances in Chemistry, Ser. 45, R. F. Gould, ed., pp. 170-176, American Chemical Society, Washington, DC.

Kohler, C., S. B. Ross, B. Srebro, and S.-O. Ogren (1978) Long-term biochemical and behavioural effects of p-chloroamphetamine in the rat. Ann. NY Acad. Sci. 305: 645-663.

Kuhar, M. J., P. J. Whitehouse, J. R. Unnerstall, and H. Loats (1984) Receptor autoradiography: Analysis using a PC-based imaging system. Soc. Neurosci. Abstr. 10:558.

Largent, B. L., A. L. Gundlach, and S. H. Snyder (1984) Psychotomimetic opiate receptors labeled and visualized with $(+)\left[{ }^{3} \mathrm{H}\right] 3-(3-$ Hydroxyphenyl)-N-(1-propyl)piperidine. Proc. Natl. Acad. Sci. USA 81: 4983-4987.

Largent, B. L., A. L. Gundlach, and S. H. Snyder (in press) Pharmacological and autoradiographic discrimination of sigma and phencyclidine receptor binding sites in brain with $(+)\left[{ }^{3} \mathrm{H}\right] \mathrm{SKF} 10,047,(+)\left[{ }^{3} \mathrm{H}\right] 3-\mathrm{PPP}$ and $\left[{ }^{3} \mathrm{H}\right]$ TCP. J. Pharmacol. Exp. Ther.

Lee, M., A. L. Gundlach, and J. C. Strahlendorf (1985) Electrophysiological effects of 3-(3-hydroxyphenyl)-N-(1-propyl)piperidine on spontaneously active cerebellar Purkinje neurons. Soc. Neurosci. Abstr. 11: 690 .

Luparello, T. J. (1967) Stereotaxic Atlas of the Forebrain of the Guinea Pig, Karger, Basel

Markstein, R., and D. Lahaye (1983) In vitro effect of the racemic mixture and the (-)enantiomer of N-n-propyl-3-(3-hydroxyphenyl)piperidine (3-PPP) on postsynaptic dopamine receptors and on a presynaptic dopamine autoreceptor. J. Neural Transm. 58: 43-53.

Martin, B. R., J. S. Katzen, J. A. Woods, H. L. Tripathi, L. S. Harris, and E. L. May (1984) Stereoisomers of $\left[{ }^{3} \mathrm{H}\right]-N$-allylnormetazocine bind to different sites in mouse brain. J. Pharmacol. Exp. Ther. 231: 539-544.

Martin, W. R., C. G. Eades, J. A. Thompson, R. E. Huppler, and P. E. Gilbert (1976) The effects of morphine- and nalorphine-like drugs in the nondependent and morphine-dependent chronic spinal dog. J. Pharmacol. Exp. Ther. 197: 517-532.

McPherson, G. A. (1983) A practical computer-based approached to the analysis of radioligand binding experiments. Comput. Prog. Biomed. 17: 107-114.

Mendelsohn, L. G., V. Kalra, B. G. Johnson, and G. A. Kerchner (1985) Sigma opioid receptor: Characterization and co-identity with the phencyclidine receptor. J. Pharmacol. Exp. Ther. 233: 597-602.

Mulder, A. H., R. Draper, P. Sminia, A. N. M. Schoffelmeer, and J. C. Stoof (1985) Agonist and antagonist effects of 3-PPP enantiomers on functional dopamine autoreceptors and postsynaptic dopamine receptors in vitro. Eur. J. Pharmacol. 107: 291-297.

Neckers, L. H., L. Bertilsson, S. H. Koslow, and J. L. Meek (1976) Reduction of tryptophan hydroxylase activity and 5-hydroxytryptamine concentration in certain rat brain nuclei after $P$-chloroamphetamine. J. Pharmacol. Exp. Ther. 196: 333-338.

Paxinos, G., and C. Watson (1982) The Rat Brain in Stereotaxic Coordinates, Academic, Sydney

Ralis, H. M., R. A. Beesley, and Z. A. Ralis (1973) Techniques in Neurohistology, Butterworth's, London.

Schwarcz, R., T. Hökfelt, K. Fuxe, G. Jonsson, M. Goldstcin, and L. Terenius (1979) Ibotenic acid-induced neuronal degeneration: A morphological and neurochemical study. Exp. Brain Res. 37: 199_ 216.

Schwarcz, R., W. D. Whetsell, Jr., and R. M. Mangano (1983) Quinolinic acid: An endogenous metabolite that produces axon-sparing lesions in rat brain. Science 219: 316-318.

Shannon, H. E. (1983) Pharmacological evaluation of $\mathrm{N}$-allylnormetazocine (SKF 10,047) on the basis of its discriminative stimulus properties in the rat. J. Pharmacol. Exp. Ther. 225: 144-152.

Slifer, B. L., and R. L. Balster (1983) Reinforcing properties of stereoisomers of the putative sigma agonists $N$-allylnormetazocine and cyclazocine in rhesus monkeys. J. Pharmacol. Exp. Ther. 225: 522-528.

Sminia, P., and A. H. Mulder (1983) Failure of 3-PPP to activate dopamine autoreceptors in vitro. Eur. J. Pharmacol. 89: 183-184.

Su, T.-P. (1981) Psychotomimetic opioid binding: Specific binding of [ $\left.{ }^{3} \mathrm{H}\right] \mathrm{SKF}-10047$ to etorphine-inaccessible sites in guinea-pig brain. Eur. J. Pharmacol. 75: 81-82.

$\mathrm{Su}, \mathrm{T}$.-P. (1982) Evidence for sigma opioid receptor: Binding of $\left[{ }^{3} \mathrm{H}\right] \mathrm{SKF}$ 
10,047 to etorphine-inaccessible sites in guinea-pig brain. J. Pharmacol. Exp. Ther. 223: 284-290.

Tam, S. W. (1983) Naloxone-inaccessible $\sigma$ receptor in rat central nervous system. Proc. Natl. Acad. Sci. USA 80: 6703-6707.

Tam, S. W. (1985) $(+)-\left[{ }^{3} \mathrm{H}\right]$ SKF $10,047,(+)-\left[{ }^{3} \mathrm{H}\right]$ ethylketocyclazocine, $\mu, \kappa, \delta$ and phencyclidine binding sites in guinea pig brain membranes. Eur. J. Pharmacol. 109: 33-41.

Tam, S. W., and L. Cook (1984) $\sigma$ opiates and certain antipsychotic drugs mutually inhibit $(+)-\left[{ }^{3} \mathrm{H}\right] \mathrm{SKF} 10,047$ and $\left[{ }^{3} \mathrm{H}\right]$ haloperidol binding in guinea pig brain membranes. Proc. Natl. Acad. Sci. USA 81: 5618-5621.

Ungerstedt, U. (1971) Postsynaptic supersensitivity after 6-hydroxydopamine induced degeneration of the nigro-striatal dopamine system. Acta Physiol. Scand. (Suppl.) 367: 69-73.

Unnerstall, J. R., D. L. Niehoff, M. J. Kuhar, and J. M. Palacios (1982) Quantitative receptor autoradiography using $\left[{ }^{3} \mathrm{H}\right]$ Ultrofilm: Appli- cation to multiple benzodiazepine receptors. J. Neurosci. Methods 6: 59-73.

Vaupel, D. B. (1983) Naltrexone fails to antagonize the effects of PCP and SKF 10,047 in the dog. Eur. J. Pharmacol. 92: 269-274.

Young, G. A., and N. Khazan (1984) Differential neuropharmacological effects of mu, kappa and sigma opioid agonists on cortical EEG power spectra in the rat. Neuropharmacology 23: 1161-1165.

Zukin, S. R., and R. S. Zukin (1979) Specific [ $\left.{ }^{3} \mathrm{H}\right]$ phencyclidine binding in rat central nervous system. Proc. Natl. Acad. Sci. USA 76: 53725376.

Zukin, R. S., and S. R. Zukin (1981) Demonstration of $\left[{ }^{3} \mathrm{H}\right]$ cyclazocine binding to multiple opiate receptor sites. Mol. Pharmacol. 20: 246254.

Zukin, S. R., K. T. Brady, B. L. Slifer, and R. L. Balster (1984) Behavioral and biochemical stereoselectivity of sigma opiate/PCP receptors. Brain Res. 294: 174-177. 